\title{
Community perceptions of local enterprises in environmentally degraded areas
}

\author{
Marina Proikaki ${ }^{\mathrm{a}}$, Ioannis Nikolaou ${ }^{\mathrm{b}}$, Nikoleta Jones ${ }^{\mathrm{c}, *}$, Chrisovaladis Malesios $^{\mathrm{d}}$, \\ Panayiotis G Dimitrakopoulos ${ }^{\mathrm{e}}$, Kostantinos Evangelinos ${ }^{\mathrm{a}}$ \\ ${ }^{a}$ Department of Environment, University of the Aegean, Mytilene, 81100, Greece \\ b Department of Environmental Engineering, Democritus University of Thrace, Vas. Sofias 12, Xanthi, 67100, Greece \\ ' Global Sustainability Institute, Anglia Ruskin University, Cambridge, CB11PT, UK \\ d Department of Agricultural Development, Democritus University of Thrace, 193 Pantazidou Str., Orestiada, GR68200, Greece \\ ${ }^{\mathrm{e}}$ Biodiversity Conservation Laboratory, Department of Environment, University of the Aegean, Mytilene, Lesbos 811 00, Greece
}

\section{A R T I C L E I N F O}

\section{Keywords:}

Corporate Social Responsibility (CSR)

Citizens' perception

Sustainable development

Water quality

\begin{abstract}
A B S T R A C T
Local enterprises can play a key role in the economic development of communities in which they are situated but simultaneously, they are often a contributor to negative impacts on the natural environment. Several studies have highlighted the importance of Corporate Social Responsibility (CSR) activities in order to strike a balance between socio-economic and environmental impacts in such communities. However, there is very limited literature exploring community perceptions of local businesses. We consider this to be a key topic as such information can be used in order to develop socio-economic and environmental policies based on the principles of sustainable development. In this paper, the results of an empirical study examining local community perceptions of business activities are presented and also perceptions regarding the contribution of firms, through CSR actions, to environmental quality restoration. The empirical study was conducted in communities located in the environmentally degraded area of the Asopos river in Greece.
\end{abstract}

\section{Introduction}

Firms are often responsible for environmental degradation issues such as biodiversity loss, soil degradation, ozone depletion, global warming and decreasing water quality (Capelle-Blancard and Laguna, 2010; Ercolano et al., 2014; Frank et al., 2016; Ogwu, 2016; Shrivastava, 1995a; Ercolano, 2014). It has been supported that even SMEs, which may have a lower impact on the natural environment due to their size, are also responsible for over $70 \%$ of environmental pollution incidents (Adekola et al., 2016; Hillary, 2004; Pineiro Chousa et al., 2017). This responsibility for environmental problems has lead different groups of local or global stakeholders to express their concerns regarding business operations. These concerns vary according to the sector in which firms operate (e.g. the mining industry) and the status of the area in which they are located (e.g. environmental degraded area, industrial zone). Stakeholders often focus on certain sectors such as the mining, chemical or oil industries due to the high health and financial risks linked with their establishment and operations. Evidence has been identified in the literature regarding the relationship of industrial environmental accidents and health and safety problems of local communities, such as the Bhopal chemical accident, Three Mile Island and the Chernobyl disaster (Hoffman, 1999). The severity of an environmental accident on the economic position of a firm, the whole sector and the local communities has a critical influence on the attitudes of stakeholders towards the business (Sy and Tinker, 2013; Zyglidopoulos, 2001). Rationally, the financial sector (the banking sector, stock exchange and investors) pays greater attention to the effects of environmental accidents and future environmental regulations on their financial position (e.g. the ability of firms to repay loans), while local communities demand better quality of life and an improved natural environment (McDermott et al., 2014).

Focusing on local communities, there is significant evidence of conflicts occurring between local residents and firms causing environmental problems. This is more obvious in the extractive industry where protests from local communities are influenced by previous experiences of large scale accidents and the level of pollution in local natural resources (Harvey, 2014; Kitula, 2006). This is especially important in areas affected by river contamination due to industrial activities, making the improvement of water quality essential in order to provide multiple benefits for local communities (Halkos and Matsiori, 2014). To

\footnotetext{
* Corresponding author.

E-mail address: nikoleta.jones@anglia.ac.uk (N. Jones).
} 
avoid such tensions and gain local "license to operate", firms can implement certain CSR activities in order to incorporate environmental and social concerns into mainstream management processes (Malovics et al., 2008; Shrivastava, 1995b). The relevant literature indicates numerous CSR activities focusing on different internal and external financial, environmental and social issues (Hall and Jeanneret, 2015; Moon, 2007). For example, the triple-bottom-line approach (economic, environmental and social factors) and the internal-external-orientation of CSR activities has been a central policy of the European Commission in the past two decades as part of its' efforts to encourage European firms to operate in a more socially responsible manner and to contribute to sustainable development (E.C., 2001). It is encouraging that previous studies have indicated a positive relationship between CSR activities and the economic, environmental and social performance of firms (Szekely and Knirsch, 2005; Torugsa et al., 2012).

An important topic examined in this field is how CSR activities can assist in resolving conflicts between stakeholders and contribute to rewarding firms with better CSR performance. A large number of studies have focused on the level of consumer trust of CSR (Kim et al., 2015) activities, the socially responsible behavior of investors (Cordeiro and Tewari, 2015), the reaction of local communities to business operations and the engagement of NGOs in corporate strategic management (Dawkins and Lewis, 2003). Literature on consumers includes studies examining the preferences and willingness of consumers to pay a premium for products produced following sustainable principles (Vlachos et al., 2009; Grebitus et al., 2016; Vasileiou and Georgantzis, 2015). Costaldo et al. (2009) highlight that consumers demonstrate greater confidence in firms undertaking CSR activities and adopting ethical codes. Ethical consumerism underlines the social and environmental impacts of local firms, involving buying from businesses whose strategies are ethical and boycotting those whose behavior seems unethical, especially for issues related to working conditions (Brown, 2015), the natural environment (Liu et al., 2014), gender equality (Jones et al., 2017), racial discrimination and human rights (Mc Gregor and Smit, 2017). Some studies have also examined the ethical parameters involved in investment decisions (i.e. selecting a portfolio with ethically and socially responsible firms) (Sparkes and Cowton, 2004). Additionally, shareholder activism and collaboration in CSR activities with NGOs demonstrates the preference of investors for socially responsible firms (Guay et al., 2004; Jonker and Nijhof, 2006). Finally, other studies explore the requests of local communities for certain CSR activities, mainly in relation to the mining industry, ensuring health and safety and a good quality of the natural environment in their local area (Imbun, 2007). Such studies examine the behavior of different groups of stakeholders regarding CSR activities and can be classified into two major categories: firstly, those that emphasize how stakeholder groups play a critical role in businesses adapting CSR activities (Batres-Perez et al., 2012) and secondly, those which explore how different groups of stakeholders react to CSR activities (Lee and Shin, 2010). Research on the second aspect is limited, especially when focusing on perceptions of local communities regarding CSR activities.

This paper aims to contribute to this literature by examining local community perceptions regarding the activities of local firms in environmentally degraded areas where a decline in economic growth has also been observed and the economic position of residents has gradually deteriorated. A significant focus of the paper will also be on describing factors explaining the perceptions of citizens. In order to explore the above issues, the results of an empirical study, implemented in the Asopos river area of Greece, are presented. The specific case study was selected as it includes communities which have experienced significant environmental degradation in the past decades mainly due to high polluting industries in the nearby area. As a result, significant socioeconomic and environmental impacts have developed for local communities and conflicts have emerged between locals and the businesses. In the next section, we will discuss the main theoretical framework on which the empirical study was designed and in the third part, the main research techniques used will be explained. This is followed by a detailed presentation of the results of the study. In the final sections, the main findings and the contribution of the paper will be highlighted.

\section{Theoretical background}

Corporate responsibility towards society is not a new concept. It originates from the 1929 stock market crash where businesses and the financial sector were considered responsible for the ensuing economic hardships of society. In 1932, Berle and Dodd advocated that the business community has two major goals -to increase shareholder wealth and to provide society with specific services (Okoye, 2009). The popularity of CSR was enhanced by the seminal book of Bowen (1953), 'The Social Responsibility of the Businessman' where the ethical role of the businessman in market and society was underlined. Many other academic studies have had a critical role in the development of the debate around corporate social responsibility extending the scope of firms by incorporating some significant topics into their processes and management, not only for shareholders (Friedman, 1970) but also for stakeholder needs (Russo and Perrini, 2010; Zhu et al., 2014). These include additional legislative, ethical and philanthropic responsibilities in addition to their economic obligations (Carroll, 1991), for strategic management issues (Branco and Rodrigues, 2006; Rupp et al., 2015) and for achieving triple bottom line goals (Elkington, 1997).

Another significant body of literature highlights the relationship of investors and CSR activities (McLachlan and Garner, 2004). In these studies, the proposed methodologies aim to assist investors in evaluating the socially and environmentally responsible behavior of firms in order to suitably adapt their investment decisions (Basso and Funari, 2014; Rubio and Vasquez, 2016). They identify three major types of behavior, namely ethically-oriented investors (Traore, 2016) and socially-risk adverse investors or socially-profit seeking investors (Bansal and DesJardine, 2014). The former category is motivated by ethical (positive or negative screening) criteria to invest in a firm (e.g. avoiding investments in the alcohol and tobacco industries or promoting investments in philanthropic and social enterprises). The latter includes investors who prefer to focus on socially responsible organizations in order to protect their investment from future financial risks (e.g. environmental accidents) or to exploit new opportunities from socially responsible firms (e.g. investing in the Dow Jones Sustainable Group Index).

Despite these significant developments in the literature, limited academic work has focused on linking perceptions of local communities and CSR activities. The limited studies that exist mainly explore conflicts occurring between local communities and businesses, especially in the extractive sector (Imbun, 2007; Bansal and DesJardine, 2014). An indicative example is the studies by Moffat and Zhang (2014) who conducted several surveys exploring the attitudes of citizens regarding the extractive processes of the mining industry. According to their findings, public trust has been affected by impacts of the mining industry on social infrastructure (e.g. positive impacts include local employment and training programs while negative impacts comprise those on social services and any deterioration in residents' health), existing links between the local community and the mining industry, and the level of engagement of local people in decision making. Despite the limited evidence, several factors can be expected to influence community perceptions of local businesses, such as the current environmental status of the area where the businesses are located (Behr et al., 2013) and the level of place attachment of the residents to the area (Manzo and Devine-Wright, 2013). Public awareness of environmental problems (Gifford and Nilsson, 2014) is another important factor influencing perceptions regarding businesses, as it affects attitudes and skills among members of the local community and other stakeholders (Frank et al., 2017). The economic relationship between firms and communities can influence local perceptions for enterprises especially considering their impact on employment rates (Beltran, 2016). As 
regards demographic factors, previous studies have revealed that educational level is a significant parameter as those with higher education tend to be more aware of environmental issues (Chawla and Cushing, 2007; Read et al., 1994). Furthermore, younger people are expected to have a greater level of environmental awareness (Stragham and Robberts, 1999), as age is an key factor affecting the tendency to be environmentally responsible and influencing environmental attitudes (Liobikiene and Juknys, 2016). Finally, although some studies exploring the impact of gender are inconclusive (Dietz et al., 1998; Han et al., 2011), there is evidence that women, with high levels of environmental awareness, have greater pro-environmental behavior compared to men (Weber et al., 2014).

In this context, a social survey implemented in an industrial area of Greece focusing on two main issues is presented: a) local community perceptions and awareness of local enterprises and related CSR activities and b) factors explaining these perceptions focusing in particular on environmental awareness and demographics. These two research questions are important as local communities can be a driving force for firms to undertake CSR activities as several of them implement CSR activities to gain legitimacy from communities and as prior to the development of any public policy and CSR strategy.

\section{Methods}

\subsection{Research area}

In order to explore the above issues, an empirical study was conducted through the distribution of structured questionnaires in the Asopos river area in Greece. The river is situated in East Central Greece with a length of approximately $57 \mathrm{~km}$ emptying into the Evoikos Bay near the area of Oropos. The river crosses one of the main motorways of Greece linking the two largest cities of the country (Athens and Thessaloniki) and the crossing point is approximately $60 \mathrm{~km}$ from the capital Athens. As a result in the 1960s, it was considered an ideal location for the establishment of new industries, adequately far from the already highly congested and polluted capital but also at a commutable distance. An increasing number of enterprises were gradually established, especially in the 1980s and 1990s including those considered as high polluters. However, due to the lack of enforcement of environmental regulations on waste disposal in the past decades, untreated industrial waste was dumped in the river causing significant environmental degradation to the water table (Botsou et al., 2011). As a result, considerable conflict emerged between the local community and the firms. Due to the concerns about water contamination, several studies have been published regarding the levels of environmental quality in the Asopos river area (Botsou et al., 2011; Lili et al., 2015). A recent interesting study also estimated the willingness to pay of local households in order to recover levels of environmental quality in the river (Tentes and Damigos, 2016). However, no study has explored, to our knowledge, community perceptions for local industries in the area and the factors explaining these perceptions. This is an important issue that needs to be explored in order to provide evidence for the wider discussion on how development in the area can be achieved based on the principles of sustainable development.

\subsection{Research questionnaire and sampling}

In order to explore perceptions a semi-structured questionnaire was distributed to a sample of the population in 21 local communities located near the river or affected by environmental degradation due to the contaminated water table in the wider area of the Asopos river. The questionnaire was distributed during the summer of 2014 as part of a larger research project (INSPIRED) by experienced researchers. The total sampling frame for the distribution of the structured questionnaires in the area was estimated to be 30,000 individuals based on data available from the 2011 census by the Hellenic Statistical
Authority. A sample of 1,000 households was approached in order to secure an adequate amount of data for the statistical analysis, which is also representative of the actual population. The number of participants from each community was determined based on the population of the communities in the sampling frame. A simple random sampling technique was applied that allows the drawing of valid conclusions about the entire population of the region based on the selected sample. Specifically, for selecting the sample size of the finite population $\left(n_{\text {finite }}\right)$ of a total size of $N \approx 30.000$ population, the following formula was utilized:

$n_{\text {finite }}=\frac{N \cdot n}{N+n-1}$

where

$n=\frac{t^{2} \widehat{p}(1-\widehat{p})}{e^{2}}$

and

$\hat{p}=\frac{\sum_{i=1}^{n}\left(p_{i}\right)}{n}$

The latter formula (3) denotes the estimation of population proportion sharing a certain characteristic on one of the dichotomous variables in the survey. $(e)$ denotes the acceptable proportion of error between the sampling proportion and the unknown proportion of the population ( $e=3 \%$ was chosen). (For a confidence level of $95 \%$, $t=1.96$ ). In addition, according to the pilot survey conducted prior to the final distribution, the higher proportion value was $\hat{p}=0.50$, and the required total sample size $n$ is thus determined to be approximately $n_{\text {finite }}=1000$.

The questionnaire consisted of several parts. Demographic data were collected regarding gender, income, age, years of residency in the area, education and employment in local enterprises. Another set of questions explored perceptions regarding the level of environmental quality in the area referring to biodiversity, water and air but also encompassing perceptions on the severity of the problem. A different set of questions explored awareness of CSR activities by local enterprises, whether individuals have communicated with local enterprises and finally the impact of local enterprises on the sustainable development of the local community. The majority of the questionnaires were distributed through face-to-face interviews while 500 postal questionnaires were also sent in order to increase the response rate. Approximately $80 \%$ of participants agreed to participate in the face-to-face interviews, and $10 \%$ of the postal questionnaires were returned. In total, 858 questionnaires were collected. The demographics of the participants (Table A.1) were cross-checked in relation to the demographics of the actual population confirming that the sample characteristics were close to the real population with a higher frequency observed for male respondents. This was because the survey was conducted at a household level and on certain occasions, male respondents were more willing to reply to the survey compared to women in the same household.

Analysis of data was conducted using the SPSS 21.0 software (IBM Corp. Released, 2012). The majority of questions were of a 5-point Likert scale with a few dichotomous type questions (YES/NO). Appropriate statistical techniques were used in order to explore links between variables ( $t$-tests, Chi-square, ANOVA, Pearson's correlation coefficient $r$, Spearman's Rho correlation coefficient $r_{s}$ ).

\section{Results}

\subsection{Perceptions regarding environmental quality in the area}

A first issue that was explored concerned perceptions of the level of local environmental quality. $74.45 \%$ of the participants considered that there is an environmental problem in the Asopos River and the severity 
Table 1

Perceptions for environmental quality in the area (scale 1-5, 5 representing highest environmental quality).

\begin{tabular}{llllll}
\hline Quality & $\begin{array}{l}\text { Very } \\
\text { poor } \% \\
(1)\end{array}$ & $\begin{array}{l}\text { Poor } \% \\
(2)\end{array}$ & $\begin{array}{l}\text { Acceptable } \% \\
(3)\end{array}$ & $\begin{array}{l}\text { Good \% } \\
(4)\end{array}$ & $\begin{array}{l}\text { Very } \\
\text { good \% } \\
(5)\end{array}$ \\
\hline $\begin{array}{c}\text { Environmental } \\
\text { quality (general) }\end{array}$ & 11.6 & 16.1 & 25.7 & 24.4 & 22.2 \\
$\begin{array}{c}\text { Drinking water } \\
\text { quality }\end{array}$ & 20.7 & 17.3 & 19.6 & 20.5 & 21.9 \\
$\begin{array}{c}\text { Biodiversity } \\
\text { Air quality }\end{array}$ & 11.6 & 19.6 & 26.1 & 22.9 & 19.8 \\
Soil quality & 10.8 & 10.1 & 17.1 & 29.2 & 32.9 \\
\hline & 10.0 & 15.5 & 24.2 & 25.0 & 25.4 \\
\hline
\end{tabular}

of the water and soil contamination was considered very high with an average score of 4.57 out of 5 (std. deviation: $0.84,5$ representing the most severe). Lowest scores were observed regarding drinking water, with $38 \%$ of participants rating quality of drinking water as 'low' and 'very low'. Similarly $31.2 \%$ of the respondents evaluated as 'low' or 'very low' the quality of local biodiversity. Equally, the lowest scores of quality evaluation were concentrated in air quality, with a $20.9 \%$ evaluation as 'low' and 'very low' and the soil quality (very low level: $15.5 \%$ ). The general environmental quality is also negatively rated by a high proportion of respondents $(27.7 \%)$ as low and very low quality (Table 1).

\subsubsection{Factors explaining perceptions of local environmental quality}

Data analysis revealed that individuals who considered that there is an environmental problem in the area also perceived a lower level of environmental quality in all aspects explored, compared to individuals who considered that there is no environmental degradation in the Asopos river (Table 2). According to the results, individuals who tend to consider the problem of pollution as important also evaluate environmental quality $\left(r_{s}=-0.16, p<0.01\right)$, biodiversity $\left(r_{s}=-0.18\right.$, $p<0.01)$, air quality $\left(r_{s}=-0.18, p<0.01\right)$ and soil quality $\left(r_{s}=-0.17, p<0.01\right)$ as low in the area.

Differences between gender were observed regarding the perceived level of environmental quality in the area, with men considering that environmental quality is better (mean 3.35 out of 5 where 5 is the highest environmental quality) compared to women (mean: 3.19 out of 5) $(t=10.028, p<0.01)$. Furthermore, female participants were more concerned about the level of degradation in the area, with $81.3 \%$ of women stating that there is a problem compared to $71.3 \%$ of male participants (Chi-square: 9.752, $p<0.01$ ). Similarly, women in the sample were more concerned about the severity of the problem, with a

Table 2

Comparison of means regarding perceptions of environmental quality between individuals who consider that the area faces environmental problems and those that do not.

\begin{tabular}{|c|c|c|c|c|}
\hline & $\begin{array}{l}\text { Is there an } \\
\text { environmental } \\
\text { problem in the } \\
\text { area? }\end{array}$ & Mean & Std. deviation & $\begin{array}{l}t \text {-test } \\
\text { (Independent) }\end{array}$ \\
\hline \multirow{2}{*}{$\begin{array}{c}\text { Environmental } \\
\text { quality } \\
\text { (general) }\end{array}$} & No & 4.05 & 1.128 & $t=10.73^{* * k+k e}$ \\
\hline & Yes & 3.03 & 1.242 & \\
\hline \multirow[t]{2}{*}{ Biodiversity } & No & 3.91 & 1.292 & $t=10.85^{\text {tw.kt }}$ \\
\hline & Yes & 2.76 & 1.374 & \\
\hline \multirow[t]{2}{*}{ Soil quality } & No & 3.77 & 1.190 & $t=7.8^{* * t / k}$ \\
\hline & Yes & 3.01 & 1.256 & \\
\hline \multirow{2}{*}{$\begin{array}{l}\text { Drinking water } \\
\text { quality }\end{array}$} & No & 4.28 & 1.080 & $t=8.85^{* * *}$ \\
\hline & Yes & 3.41 & 1.322 & \\
\hline \multirow[t]{2}{*}{ Air quality } & No & 4.14 & 1.056 & $t=10.39^{\text {s.t.k }}$ \\
\hline & Yes & 3.15 & 1.266 & \\
\hline
\end{tabular}

$* * * p<0.01$
Table 3

Spearman Rho $\left(r_{s}\right)$ correlations linking perceptions of environmental quality with educational and income level.

\begin{tabular}{lll}
\hline & $\begin{array}{l}\text { Correlation with } \\
\text { educational level } \\
\text { (Spearman Rho) }\end{array}$ & $\begin{array}{l}\text { Correlation with income } \\
\text { level (Spearman Rho) }\end{array}$ \\
\hline $\begin{array}{l}\text { Environmental quality } \\
\quad \text { (general) }\end{array}$ & $-0.22^{*}$ & $-0.08 \mathrm{n} . \mathrm{s}$. \\
$\begin{array}{l}\text { Drinking water quality } \\
\text { Biodiversity }\end{array}$ & $-0.21^{*}$ & $0.027 \mathrm{n} . \mathrm{s}$ \\
Air quality & $-0.21^{*}$ & $0.020 \mathrm{n} . \mathrm{s}$ \\
Soil quality & $-0.26^{*}$ & $-0.071 \mathrm{n} . \mathrm{s}$ \\
\hline
\end{tabular}

n.s. $=$ non significant.

${ }^{*} p<0.01$.

mean score of 4.62 (out of 5 where 5 is the highest importance for the local pollution problem) compared to male respondents (4.55) $(t=4.78, p<0.05)$.

The average age of respondents who declared there to be an environmental problem was 39 compared to individuals who considered there was no environmental degradation in the area whose average age was $47(t=14.5, p<0.01)$. The severity of the problem had a negative connection, with younger individuals perceiving a lower level of severity regarding environmental pollution $(r=-0.86, p<0.05)$. A similar tendency is observed for the level of environmental quality in the area. Higher educational levels were linked with perceptions that the environmental quality in the area is low (Table 3). Similarly, individuals with a higher educational level also considered that a problem exists in the area. Only $50 \%$ of participants with the lowest level of education considered there to be a problem of environmental degradation (less than 6 years in education). This percentage increases to over $80 \%$ for other educational categories beyond secondary level (+12 years) (Chi-square: $54.50, p<0.01$ ). Income level is linked with perceptions of the severity of the problem with higher earning individuals perceiving a greater severity $\left(r_{s}=0.12, p<0.01\right)$. However, income does not influence other perceptions of individuals regarding environmental quality.

Finally, individuals who have been living in the area for a longer period consider that there is better environmental quality $\left(r_{s}=0.11\right.$, $p<0.01$ ) compared to individuals who have moved to the area more recently. Those individuals considering there to be a problem in the area have lived there on average for 29 years compared to those who considered that there was no problem where the average years of residency was $40(t=6.95, p<0.01)$. However, individuals who have lived longer in the area tend to believe that the pollution in the river is of high severity $\left(r_{s}=0.11, p<0.01\right)$.

\subsection{Awareness regarding activities of local enterprises beneficial for the local community}

According to the results of the study, $43.8 \%$ of respondents were aware of socio-cultural activities initiated by local enterprises: $26.8 \%$ were aware of financial contributions from local enterprises, $26.9 \%$ were aware of charity events, $23.8 \%$ were aware of environmental activities, 13\% mentioned support of touristic infrastructure and $21 \%$ educational activities. Finally, only $31.8 \%$ of the sample had communicated with a local enterprise regarding matters of the local community.

\subsubsection{Factors explaining citizens' knowledge and perceptions regarding the role of local enterprises}

When exploring the impact of demographics on citizens' awareness regarding local companies' activities benefiting the local community, a trend is observed where individuals of a younger age tend to be less aware of such activities (Table 4). Also, women are significantly more 
Table 4

Chi-square test and $t$-test exploring connections between gender, age and years living in the area with awareness of activities and communicating with local enterprises.

\begin{tabular}{|c|c|c|c|c|c|c|c|c|c|c|c|c|c|}
\hline & & \multicolumn{3}{|c|}{ Years in the area } & \multicolumn{3}{|l|}{ Age } & \multicolumn{3}{|c|}{ Employed in local enterprise } & \multicolumn{3}{|l|}{ Gender } \\
\hline & & $\begin{array}{l}\text { YES } \\
\text { (mean) }\end{array}$ & $\begin{array}{l}\text { NO } \\
\text { (mean) }\end{array}$ & $t$-test & $\begin{array}{l}\text { YES } \\
\text { (mean) }\end{array}$ & $\begin{array}{l}\text { NO } \\
\text { (mean) }\end{array}$ & $t$-test & $\begin{array}{l}\text { Employed and } \\
\text { Aware } \\
\text { of activities (\%) }\end{array}$ & $\begin{array}{l}\text { Not } \\
\text { employed } \\
\text { and aware } \\
(\%)\end{array}$ & $\mathrm{x}^{2}$ & $\begin{array}{l}\text { Women } \\
\text { (Yes, \%) }\end{array}$ & $\begin{array}{l}\text { Men } \\
\text { (Yes, \%) }\end{array}$ & $\mathrm{X}^{2}$ \\
\hline \multirow[t]{7}{*}{ Awareness of: } & Socio-cultural activities & 25.98 & 36.97 & $-7.98^{* * *}$ & 34.38 & 46 & $8.68^{* *}$ & 58.1 & 38.5 & $28.8^{* * *}$ & 57.8 & 38.4 & $27.84^{* * k}$ \\
\hline & Financial contributions & 28.68 & 33.34 & $-2.94^{\text {t**e }}$ & 36.22 & 42.11 & $3.99^{k * *}$ & 34 & 24.1 & $9.2^{* k \hbar}$ & 34.1 & 24.2 & $9.01^{* * k}$ \\
\hline & Charity events & 27.31 & 33.85 & $-4.15^{* * *}$ & 34.88 & 42.6 & $5.27^{* *}$ & 36.5 & 23.2 & $16.57^{\text {kik }}$ & 34.1 & 24.3 & $8.76^{* * x}$ \\
\hline & Environmental activities & 26.41 & 33.91 & $-4.60^{* * *}$ & 33.52 & 42.72 & $6.04^{* *}$ & 31.3 & 21.1 & $10.45^{k * k}$ & 27.3 & 23.0 & $1.90 \mathrm{n} . \mathrm{s}$ \\
\hline & Tourist infrastructure & 25.51 & 33.05 & $-3.61^{* * *}$ & 31.63 & 41.79 & $5.2 \mathrm{n} . \mathrm{s}$ & 18.2 & 10.9 & $8.80^{*}$ & 12.7 & 13.6 & $0.10 \mathrm{n} . \mathrm{s}$ \\
\hline & Educational activities & 26.07 & 33.74 & $-4.48^{\text {k*t }}$ & 33.69 & 42.33 & $5.38^{* * *}$ & 25.8 & 19.6 & $4.2^{3 . k}$ & 30.3 & 17.4 & $17.79^{* \ldots k}$ \\
\hline & $\begin{array}{l}\text { Communicating with local } \\
\text { enterprises }\end{array}$ & 32.74 & 32.22 & $0.34^{\text {kik }}$ & 40.64 & 40.96 & $0.22^{* *}$ & 48.1 & 23.9 & $50.42^{* k * k}$ & 31.8 & 32.4 & 0.489 n.s. \\
\hline
\end{tabular}

n.s. $=$ non significant.

** $p<0.01$.

${ }^{*} p<0.1$.

Table 5

Chi-square tests linking income and education with awareness of activities and also communicating with local enterprises.

\begin{tabular}{|c|c|c|c|c|c|c|c|c|c|c|c|c|c|c|}
\hline & & \multicolumn{7}{|c|}{ Years of education } & \multicolumn{6}{|l|}{ Income level } \\
\hline & & $0-6$ & $7-9$ & $10-12$ & $12-14$ & $14-16$ & $16+$ & $x^{2}$ & No income & $1-12,000$ & $12,000-30,000$ & $30,001-60,000$ & $\begin{array}{l}\text { Over } \\
60,000\end{array}$ & $x^{2}$ \\
\hline \multirow[t]{7}{*}{ Awareness of: } & Socio-cultural activities & 23.1 & 28.6 & 45 & 50.4 & 62.7 & 38.5 & $61.39^{\text {k*k }}$ & 61.8 & 37 & 40.5 & 45.8 & 64.3 & $37.6^{* k t}$ \\
\hline & Financial contributions & 13.2 & 21.6 & 26.3 & 31.5 & 37.8 & 26.9 & $25.97^{* * *}$ & 28.8 & 25.9 & 27.2 & 33.3 & 50 & $4.59^{*}$ \\
\hline & Charity events & 14 & 22.7 & 28 & 33.9 & 32.3 & 34.6 & $17.69^{\text {*k }}$ & 31.6 & 24.3 & 26.2 & 50 & 42.9 & $11.60^{*}$ \\
\hline & Environmental activities & 13.2 & 17.5 & 25.5 & 33.9 & 27.5 & 23.1 & $17.92^{\text {k** }}$ & 37.3 & 17.6 & 19.9 & 45.8 & 50 & $40.99^{* * *}$ \\
\hline & Touristic infrastructure & 5 & 15.5 & 15.2 & 14.5 & 14.9 & 7.7 & $9.82^{*}$ & 21.7 & 10.4 & 9.9 & 12.5 & 28.6 & $19.87^{\text {** }}$ \\
\hline & Educational activities & 13.2 & 13.4 & 16.4 & 25 & 34.3 & 30.8 & $34.40^{\text {k* }}$ & 29.7 & 16.8 & 18.8 & 25 & 35.7 & $16.18^{* * *}$ \\
\hline & $\begin{array}{l}\text { Communication with } \\
\text { local enterprises }\end{array}$ & 26 & 30.2 & 26.1 & 44.4 & 38.5 & 26.9 & $19.55^{\text {kt }}$ & 30.5 & 29.7 & 36.3 & 54.2 & 28.6 & $8.2^{*}$ \\
\hline
\end{tabular}

$* * p<0.01$.

${ }^{*} p<0.1$.

aware of such initiatives (Table 4). Statistically significant differences are presented between educational and income categories and the level of awareness of such activities. A tendency is presented where individuals with over 12 years of education and higher incomes are more aware of such initiatives (Table 5). Finally, individuals employed in local enterprises are more aware of such activities compared to individuals not working in local businesses (Table 5).

\subsection{Perceptions of the impacts of local enterprise activities}

Another set of questions explored opinions about the impact of local enterprises on the local community in relation to a variety of issues. According to respondents, the most positive impact was contribution to employment levels and the highest negative impact was on environmental quality in the area (Table 6). The influence of certain demographic characteristics on these perceptions was also explored. According to the analysis (A.2), individuals with a higher educational level, higher income and those employed in local enterprises tend to perceive local businesses as having a positive impact. Conversely, individuals who have lived longer in the area and are older tend to perceive more negative impacts from local enterprises (Table 7).

\subsection{Co-existence of local enterprises with the local community}

$31.8 \%$ of participants mentioned that they have been in touch with local enterprises for issues relevant to their local area. When exploring the impact from other demographic variables, it is clear that individuals who tend to communicate with local enterprises are male with over 12 years of education and with an income of between $€ 30,001$ and
Table 6

Perceptions of the impact of local enterprises on local communities.

\begin{tabular}{llll}
\hline Impact category & Positive (\%) & Negative (\%) & $\begin{array}{l}\text { No impact } \\
\text { (\%) }\end{array}$ \\
\hline Employment & 50 & 21.1 & 28.9 \\
Living standard & 42.7 & 23.6 & 33.6 \\
Local economy & 45.9 & 24.3 & 29.8 \\
Research \& Development & 29 & 22.4 & 48.6 \\
Support of social and cultural & 42.1 & 21.4 & 36.4 \\
$\quad$ activities & 26.1 & 31 & \\
Health & 28.5 & 34.3 & 32.9 \\
Environment & 46.9 & 18.9 & 34.2 \\
Merchandise of local product & 49.4 & 19.3 & 31.3 \\
Agricultural production & 45.3 & 21.2 & 33.5 \\
Quality of life & & & \\
\hline
\end{tabular}

$€ 60,000$. The rest of the demographic variables have a non-significant influence. Finally, higher levels of awareness regarding the actions of enterprises are also linked to more positive perceptions regarding their impacts in all issues explored (A.3).

\section{Discussion and conclusion}

The results of this study are useful in helping researchers and policy makers to understand local community perceptions of local enterprises especially in the context of communities facing low environmental quality due to industrial activity. The Asopos river area is an interesting case study as through the years the area has faced significant problems of environmental degradation due to the establishment of high polluting industries (Davila et al., 2017; Panagopoulos et al., 2014). This 
Table 7

ANOVA comparison of means exploring the influence of 'years living in the area' and 'age' on perceptions regarding the impact of local enterprise initiatives.

\begin{tabular}{|c|c|c|c|c|c|}
\hline \multirow{2}{*}{$\begin{array}{l}\text { Impact category } \\
\text { (positive) }\end{array}$} & \multirow{2}{*}{$\begin{array}{l}\text { Impact } \\
\text { Positive }\end{array}$} & \multicolumn{2}{|c|}{ Years living in the area } & \multicolumn{2}{|c|}{ Mean age } \\
\hline & & 27.37 & 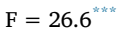 & 36.52 & $\mathrm{~F}=26.24^{* * * *}$ \\
\hline & Negative & 39.09 & & 48.35 & \\
\hline & No impact & 35.84 & & 42.67 & \\
\hline \multirow[t]{3}{*}{ Living standards } & Positive & 29.36 & $\mathrm{~F}=6.38^{* *+k i k}$ & 39.22 & $\mathrm{~F}=2.99$ \\
\hline & Negative & 34.9 & & 43.48 & \\
\hline & No impact & 34.15 & & 41.03 & \\
\hline \multirow[t]{3}{*}{ Local economy } & Positive & 28.85 & $\mathrm{~F}=10^{\text {t*k*k}}$ & 38.43 & $\mathrm{~F}=5.40^{* * * *}$ \\
\hline & Negative & 34.64 & & 43.12 & \\
\hline & No impact & 35.54 & & 42.55 & \\
\hline \multirow[t]{3}{*}{ R\&D supply } & Positive & 27.63 & $\mathrm{~F}=9.34^{* \ldots \ldots k}$ & 36.26 & $\mathrm{~F}=9.60^{* * \ldots k t}$ \\
\hline & Negative & 34.55 & & 42.56 & \\
\hline & No impact & 34.34 & & 42.83 & \\
\hline \multirow{3}{*}{$\begin{array}{l}\text { Support for social } \\
\text { and cultural } \\
\text { activities }\end{array}$} & Positive & $=28.59$ & $\mathrm{~F}=10.35^{* k * *}$ & 36.05 & $\mathrm{~F}=19.57^{* \ldots \times k}$ \\
\hline & Negative & 34.8 & & 43.57 & \\
\hline & No impact & 35.3 & & 44.74 & \\
\hline \multirow[t]{3}{*}{ Health } & Positive & 27.13 & $\mathrm{~F}=10.20^{* k * k}$ & 34.88 & $\mathrm{~F}=15.84^{* * * * *}$ \\
\hline & Negative & 35.29 & & 44.49 & \\
\hline & No impact & 33.29 & & 41.76 & \\
\hline \multirow[t]{3}{*}{ Environment } & Positive & 28.05 & $\mathrm{~F}=8.13^{* * \ldots \times k}$ & 36.17 & $\mathrm{~F}=9.65^{* \star * *}$ \\
\hline & Negative & 32.58 & & 42.45 & \\
\hline & No impact & 35.18 & & 43.00 & \\
\hline \multirow{3}{*}{$\begin{array}{l}\text { Support for local } \\
\text { products }\end{array}$} & Positive & 30.02 & $\mathrm{~F}=5.29^{* * \ldots k k}$ & 39.27 & $\mathrm{~F}=2.61^{*}$ \\
\hline & Negative & 32.95 & & 42.92 & \\
\hline & No impact & 35.19 & & 41.89 & \\
\hline \multirow{3}{*}{$\begin{array}{l}\text { Agricultural } \\
\text { production }\end{array}$} & Positive & 29.58 & $\mathrm{~F}=8.32^{* * \ldots k k}$ & 38.49 & $\mathrm{~F}=6.40^{* * 2 \times k}$ \\
\hline & Negative & 33.36 & & 43.85 & \\
\hline & No impact & 36.11 & & 42.75 & \\
\hline \multirow[t]{3}{*}{ Quality of life } & Positive & 29.68 & $\mathrm{~F}=6.19^{* \ldots * k}$ & 39.14 & $\mathrm{~F}=3.51^{* *}$ \\
\hline & Negative & 33.47 & & 43.63 & \\
\hline & No impact & 35.24 & & 41.56 & \\
\hline
\end{tabular}

$$
\begin{aligned}
& * * * p<0.01 \\
& { }^{* *} p<0.05 \\
& { }^{*} p<0.1
\end{aligned}
$$

paper also contributes to the discussion, currently taking place in Greece, regarding the role of local industries in the context of the current economic recession (Hyz and Karamanis, 2017). As the Greek government is seeking to find new policy initiatives and ways to move out of the recession (Papatheodorou and Pappas, 2017), it is important to provide evidence which will allow the inclusion of citizens' perceptions for the environmental and social responsibility of local enterprises in areas that face environmental degradation, thus leading to policies focusing on the social aspects of sustainable development and not just economic development.

Overall, the level of awareness regarding the environmental quality in the area was significantly high, with the majority of participants declaring themselves to be aware of and concerned about the low environmental quality. These perceptions are relevant to other studies that reveal the concern of citizens for local environmental hazards (Hernandez et al., 2015; Schafft et al., 2013). Regarding factors explaining these perceptions, female respondents were more concerned about the level of environmental quality confirming previous studies about gender differences where often women have a lower level of environmental knowledge compared to men but at the same time are more concerned about environmental issues (Glass et al., 2016; Kollmuss and Agyeman, 2002). In this context, previous studies have confirmed the importance of environmental behavior and involvement of women in local environmental management and conservation practices (Katz-Gerro et al., 2013).

Furthermore, younger participants were more concerned about the level of environmental quality, a fact often observed in similar studies where individuals tend to get less concerned about environmental issues as they get older (Szagun and Pavlov, 1995; Wiernik et al., 2013). This is a long established link in the literature (Dillman and Christensen, 1972) but there is evidence that there might be a gradual shift as younger individuals who tend to be more environmentally educated are expected to maintain positive environmental principles in the long term (Aminrad et al., 2011; Van Liere and Dunlap, 1980). Regarding the impact of education and income level, our results confirm previous studies regarding the role of these factors on environmental perceptions. In particular, participants who had completed over 12 years of education were significantly more concerned regarding the level of environmental quality. This is in line with previous findings where educated individuals are more concerned about environmental issues and more engaged in actions that support the protection of the natural environment (Zsoka et al., 2013).

Moreover, individuals with higher income considered that the environmental problems are more severe, confirming the link between environmental awareness and income (Franzen and Meyer, 2010). Low income level is often observed in environmentally degraded areas with residents wishing to move away, fuelling issues of social, environmental and economic decline. Furthermore, a recent study has shown that individuals from areas with low quality of life are less likely to be environmentally active (Zhao et al., 2014). Another interesting finding explaining perceptions for environmental quality is how long an individual has been a resident in a specific area. It should be noted that in Greece, the rate of geographical mobility is quite low with individuals often staying in the same area for decades (Pratsinakis et al., 2017). According to our study, individuals who have lived in the area longer tend to have a more positive perception of environmental quality levels. A potential interpretation is that individuals who have moved more recently to the area are probably not used to the situation and thus express a higher concern about local environmental depletion while individuals who have lived longer in the Asopos area are older and thus have a lower perception of and concern about the risks regarding the level of environmental quality (impact of age). However, it is interesting that those who have lived in the area for a longer period consider the problem of environmental degradation as more severe. This can be explained taking into consideration the history of the problem in the Asopos river where a decade ago the issue was much more severe as there were very limited initiatives by the government to tackle it. At the moment some industries have been fined and environmental regulations have been strengthened in Greece (Filentas and Paralikas, 2014). Moreover, individuals who have lived longer in the area will have experienced the severe clashes that emerged in the area between the local community and the industries which included conflicts with central government due to their lack of action.

A second important topic that was explored in the study concerned perceptions of local enterprises. This was a very important issue to examine, both because it fills a gap in the international literature but also because of the current economic recession in Greece and the need to build new bridges between the corporate sector and local communities. It is interesting to note that less than half of the participants were aware of CSR activities from local enterprises benefitting the local community, confirming a growing body of literature demonstrating that knowledge of CSR has a positive influence on citizens' responses, attitudes and general behavior towards local enterprises (Pathak et al., 2014). However, only a third of the sample had communicated with local enterprises about community matters. This is a disappointing finding considering the important role that local enterprises can have in creating strong ties with local communities especially during challenging financial times (Ameer et al., 2017; Greiling and Grub, 2014; Kavoura and Sahinidis, 2015; Health and Lee, 2016). Regarding the impact of demographics, male respondents, younger individuals and participants with lower income and educational levels had a lower level of awareness of the activities of local businesses. This is in accordance with previous studies revealing that more educated communities with 
higher income levels tend to be more engaged with local firms (Kim and Ferguson, 2014).

Concerning the impact of existing activities, a variety of issues were explored in the study. Employment was the most important positive impact from local enterprises. However, the valuation for the importance of this impact was surprising low, with only $50 \%$ of the sample considering this as a positive impact and $28.9 \%$ considering it as having no impact at all. Taking into consideration the large number of enterprises in the area (estimated to be 700), this was a very interesting and unexpected finding as the level of employment of the local population in these organizations is low. Several researchers underline the importance of entrepreneurial strategies focusing on the establishment of infrastructure supporting the local workforce where the main industrial activities take place (Fleming and Measham, 2014). In our study, a positive impact on local agricultural products was also evident highlighting the important role of local enterprises in improving market access for such products by reducing transaction costs (Weng et al., 2013). The most negative impact was observed on the natural environment. This is possibly linked with the perception of local communities regarding the immediate risks associated with industrial activities in the area (De Castro et al., 2017). However, it should be noted that almost a third of the sample considered that there was no impact from the existence of enterprises.

Demographic factors explaining these perceptions include the fact that individuals with a higher educational level, higher income and those employed in local enterprises tend to perceive those businesses as having a positive impact in general. On the other hand, those who have lived longer in the area and are older tend to perceive more negative impacts from local enterprises. This finding is not surprising considering that older people and those who have lived longer in the area have been significantly influenced by the long-term existence of the problem; this is in accordance with previous findings in the relevant literature (Kim and Ferguson, 2014).

A final interesting issue explored in the study concerned the existing links between local enterprises and the local community, a relationship which can be considered a core element in building communities based on the principles of sustainable development. Only a third of the sample have communicated with local enterprises, a very low percentage considering the size of these communities where the majority are of less than 10,000 inhabitants and dense local networks are to be expected (Putnam, 2000). According to the statistical analysis, men tend to communicate more with local enterprises, a fact which is possibly linked to the existence of more traditional family structures in the area and the role of women in the household. Also, higher income and educational levels are associated with better links with local businesses; this finding is possibly linked with the networks that individuals with such demographic characteristics can access (Coleman, 1990).

Despite the importance of these findings, it is useful to mention certain limitations of the current study. Firstly, a quantitative social research technique was used that captured perceptions during a specific time frame. However, as the impact of the economic recession has changed in the past years, it would be interesting to initiate a study aiming to collect longitudinal data allowing us to observe the change in perceptions towards local enterprises in the area. Secondly, the study focused on specific factors expected to influence individual perceptions of CSR activities. Additional factors need to be taken into consideration in order to further understand citizens' perceptions, including both individual parameters and indicators focusing on community (macro) level.

In conclusion, the aim of the paper was to highlight the importance of local community perceptions of local enterprises and to explore this issue in the area of the Asopos river in Greece. Thus, the importance of the study is built on two main issues. Firstly, the study highlights the need to research local community perceptions of local industries and their CSR activities, a focus which is often neglected in the literature. Secondly, the study is of a significant local and national interest as it explores CSR activities in an area which urgently needs governmental action in order to recover from environmental degradation also taking into consideration the socio-economic impacts of the current recession in Greece. The main findings of the study reveal that there are several factors to be taken into consideration when exploring perceptions of CSR activities such as education, gender and age. This is an important conclusion which has not been adequately explored in the literature. Regarding findings for the specific case study, our results reveal that there are high levels of concern about the worsening level of environmental quality in the Asopos area and it was disappointing to observe a low level of awareness regarding CSR activities from local enterprises. Common predictors such as gender, income and age were found to be important factors in explaining local community perceptions. Future research needs to focus on additional factors and the development of a framework that can be applied in different geographical and socioeconomic contexts.

\section{Acknowledgments}

This research has been co-financed by the European Union (European Social Fund ESF) and Greek national funds through the Operational Program "Education and Lifelong Learning" of the National Strategic Reference Framework (NSRF) - Research Funding Program: THALES, titled: "Incorporating sustainability in participatory decision making". Investing in knowledge society through the European Social Fund, Grand Number: 379350.

\section{Supplementary materials}

Supplementary material associated with this article can be found, in the online version, at doi:10.1016/j.socec.2018.01.007.

\section{References}

Adekola, J., Fischbacher-Smith, M., Fischbacker-Smith, D., Adekola, O., 2016. Health risks from environmental degradation in the Niger Delta Nigeria. Environ. Plann. C 35 (2), 334-354.

Ameer, R., Ameer, R., Othman, R., Othman, R., 2017. Corporate social responsibility performance communication and portfolio management. Managerial Finance 43 (5), 595-613.

Aminrad, Z., Zakaria, S.Z.B.S., Hadi, A.S., 2011. Influence of age and level of education on environmental awareness and attitude: case study on Iranian students in Malaysian Universities. Social Sci. 6 (1), 15-19.

Bansal, P., DesJardine, M.R., 2014. Business sustainability: it is about time. Strategic Org. $12(1), 40-78$.

Basso, A., Funari, S., 2014. Constant and variable returns to scale DEA models for socially responsible investment funds. Eur. J. Oper. Res. 235 (35), 775-783.

Batres- Perez, L.A., Doh, J.P., Miller, V.V., Pisani, M.J., 2012. Stakeholder pressures as determinants of CSR strategies choice: why firms choose symbolic versus substantive self-regulatory codes of conduct? J. Bus. Ethics 110 (2), 157-172.

Behr, J., Eisenhauer, M., Brian, W., Stedman, R., 2013. Environmental concern: examining the role of place meaning and place attachment. Society Nat. Resour. 26 (5), $522-538$.

Beltran, A., 2016. Does corruption increase or decrease employment in firms? Appl. Econ. Lett. 23 (5), 361-364.

Botsou, F., Karagoergis, A.P., Dassenakis, E., Scoullos, M., 2011. Assessment of heavy metal contamination and mineral magnetic characterization of the Asopos river sediments (Central Greece). Mar. Pollut. Bull. 62 (3), 547-563.

Bowen, H.R., 1953. Social Responsibilities of the Businessman. Harper \& Row, New York.

Branco, M.C., Rodrigues, L.L., 2006. Corporate social responsibility and resource-based perspectives. J. Bus. Ethics 69 (2), 111-132.

Brown, G.D., 2015. Effective protection of workers health and safety in global supply chains. Int. J. Labour Res. 7 (1/2), 35.

Capelle-Blancard, G., Laguna, M.A., 2010. How does the stock market respond to chemical disasters? J. Environ. Econ. Manage. 59 (2), 192-205.

Carroll, A., 1991. The pyramid of corporate social responsibility toward the moral management of organizational stakeholders. Bus. Horiz. 34 (4), 39-48.

Chawla, L., Cushing, D.F., 2007. Education for strategic environmental behavior. Environ. Edu. Res. 13 (4), 437-452.

Coleman, J.S., 1990. Foundations of Social Theory. Belknap Press of Harvard University Press, Cambridge, MA.

Cordeiro, J.J., Tewari, M., 2015. Firm characteristics, industry context and investor reactions to environmental CSR: a stakeholder theory approach. J. Bus. Ethics 130 (4), 833-849.

Costaldo, S., Francesco, P., Nicolas, M., Antonio, T., 2009. The missing link between 
corporate social responsibility and consumer trust: the case of fair trade products. J. Bus. Ethics 84 (1), 1-15.

Davila, O.G., Koundouri, P., Pantelidis, T., Papandreou, A., 2017. Do agents characteristics affect their valuation of common pool resources? A full preference ranking analysis for the value of sustainable river basin management. Sci. Total Environ. 575, $1462-1469$.

Dawkins, J., Lewis, S., 2003. CSR in stakeholder expectations: and their implication for company strategy. J. Bus. Ethics 44, 185-193.

De Castro, T.C.S., Castro, A.C.L., Soares, L.S., Silva, M.H.L., Ferreira, H.R.S., de Jesus Azevedo, W., de Franka, V.L., 2017. Social and environmental impacts on rural communities residing near the industrial complex of Sao Luis island, State of Marannao, Brazil. J. Sustainable Dev. 10 (2), 249.

Dietz, T., Stern, P.C., Guagnano, G.A., 1998. Social structure and social psychological bases of environmental concern. Environ. Behav. 30 (4), 450-471.

Dillman, D.A., Christensen, J.A., et al., 1972. The public value of pollution control. In: Burch, W. (Ed.), Social Behavior, Natural Resources and the Environment. Harper \& Row, New York, pp. 237-256.

E.C., 2001. Promoting a European Framework for Corporate Social Responsibility. Office for Official Publications of the European Communities, Luxemburg Green Paper.

Elkington, J., 1997. Cannibals with Forks: The Triple Bottom Line of 21st Century Business. Capstane, Oxford, pp. 73.

Ercolano, S., Gaeta, G.L., Romano, O., 2014. Environmental tax reform and individual preferences: an empirical analysis on European micro data. J. Behav. Exp. Econ. 51 (1), 1-11.

Ercolano, S., 2014. Cross Regional Heterogeneity of Individual Attitudes Towards Public Management of Local Services. An Empirical Analysis Based on Italian Data. Economia dei Servizi 9 (3), 259-270.

Filentas, F., Paralikas, A., 2014. Legal tools of environmental liability in Greece: application in the broader region of Asopos. Int. J. Environ. Sustainable Dev. 13 (3), 224-238.

Fleming, D.A., Measham, T.G., 2014. Local job multipliers of mining. Resour. Policy 41, 9-15.

Frank, A.G., Dalle-Molle, N., Gerstlberger, W., Bernardi, J.A.B., Perdini, D.C., 2016. An integrative environmental performance index for benchmarking in oil and gas industry. J. Cleaner Prod. 133, 1190-1207.

Frank, C., Kairo, J.G., Bosire, J.O., Mohamend, M.O., Dahdouh-Guebas, F., Koedam, N., 2017. Involvement, knowledge and perception in an natural reserve under participatory management: Mida Creek, Kenya Ocean Coastal Manage. 142, pp. 28-36.

Franzen, A., Meyer, R., 2010. Environmental attitudes in cross-national perspective: a multilevel analysis of the ISSP 1993 and 2000. Eur. Sociol. Rev. 26 (2), 219-234.

Friedman, M., 1970. The responsibility of business is to increase its profits. New York Time Mag. 32-33, 122-124.

Gifford, R., Nilsson, A., 2014. Personal and social factors that influence pro-environmental concern and behavior: a review. Int. J. Phycol. 49 (3), 141-157.

Glass, C., Cook, A., Ingersoll Alicia, R., 2016. Do women leaders promote sustainability? Analyzing the effect of corporate governance composition on environmental performance. Bus. Strategy Environ. 25 (7), 495-511.

Grebitus, C., Steiner, B., Veeman, M.M., 2016. Paying for sustainability: a cross-cultural analysis of consumers' valuations of food and non-food products labeled for carbon and water footprints. J. Behav. Exp. Econ. 63, 50-58.

Greiling, D., Grub, B., 2014. Sustainability reporting in Austrian and German local public enterprises. J. Economic Policy Reform 17 (3) Critical Issues in Public Enterprise, Reform.

Guay, T., Doh, J.P., Sinclair, G., 2004. Non-governmental organizations, shareholder activism, and socially responsible investments: ethical, strategic and governance. J. Bus. Ethics 52 (1), 125-139.

Halkos, G., Matsiori, S., 2014. Exploring social attitude and willingness to pay for water resources conservation. J. Behav. Exp. Econ. 49, 54-62.

Hall, N.L., Jeanneret, T., 2015. Social license to operate an opportunity to enhance CSR for deeper communication and engagement: corporate communications. Int. J. 20 (2), 213-227.

Han, H., Hsu, L.-T.J., Lee, J.-S., Sheu, C., 2011. Are lodging customers ready to go green? An examination of attitudes, demographic, and eco-friendly intentions. Int. J. Hospitality Manage. 30, 345-355.

Harvey, B., 2014. Social development will not deliver social license to operate for the extractive sector. Extr. Ind. Soc. 1 (1), 7-11.

Health, R.L., Lee, J., 2016. Chemical manufacturing and refining industry legitimacy: reflecting management, trust, precrisis communication to achieve community efficacy. Risk Anal. 36 (6), 1108-1124.

Hernandez, M., Collins, T., Grineski, S.E., 2015. Immigration, mobility and environmental injustice: a comparative study of Hispanic people's residential decision making and exposure to hazardous air pollutant sin Greater Houston Texas. Geoforoum 60, 83-94.

Hillary, R., 2004. Environmental management systems and the smaller enterprise. J. Cleaner Prod. 12 (6), 561-569.

Hoffman, A.J., 1999. Institutional evolution and change: environmentalism and the U.S. chemical industry. Acad. Manage. J. 42 (4), 351-371.

Hyz, A., Karamanis, K., 2017. The role of the creative industries in regional development during the economic cycle: case of the region of Epirus, Greece. Int. J. Entrepreneurship Innovation Manage. 21 (3), 170-184.

IBM, SPSS. IBM Corp. Released 2012. IBM SPSS. Statistics for Windows.

Imbun, B.Y., 2007. Cannot manage without the 'significant other': mining, corporate social responsibility and local communities in Papua New Guinea. J. Bus. Ethics 73, 177-192.

Jones, R.J., Reilly, T.M., Cox, M.Z., Cole, B.M., 2017. Gender makes a difference: investigating consumer purchasing behavior and attitudes toward corporate social responsibility policies. Corporate Social Responsibility Environ. Manage. 24 (2), 133-144.

Jonker, J., Njhof, A., 2006. Looking through the eyes of others: assessing mutual expectations and experiences in order to shape dialogue and collaboration between business and NGOs with respect to CSR. Corporate Governance 14 (5), 456-466.

Katz-Gerro, T., Greenpan, I., Handy, F., Lee, H.Y., Frey, A., 2013. Environmental philanthropy and environmental behavior in five countries: is there convergence among youth? VOLUNTAS: International Journal of Voluntary and Nonprofit Organizations 26 (4), 1485-1509.

Kavoura, A., Sahinidis, A.G., 2015. Communicating corporate social responsibility activities in Greece in a period of a prolonged economic crisis. Procedia-Social Behav. Sci. 175, 495-502.

Kim, S., Ferguson, M.A.T., 2014. Public expectations of CSR communication: why and how to communicate CSR. Public Relat. J. 8 (3), 1-22.

Kim, H., Hur, W.-M., Yeo, J., 2015. Corporate brand trust as a mediator in the relationship between consumer perceptions of CSR. Corporate hypocrisy and corporate reputation. Sustainability 7 (4), 3683-3694.

Kitula, A.G.N., 2006. The environmental and socio-economic impacts of mining on local livelihoods in Tanzania: a case study of Geita district. J. Cleaner Prod. 14 (3), 405-414.

Kollmuss, A., Agyeman, J., 2002. Mind the gap: why do people act environmentally and what are the barriers to pro-environmental behavior? Environ. Edu. Res. 8 (3), 239-260.

Lee, K.-H., Shin, D., 2010. Consumers' responses to CSR activities: the linkage between increased awareness and purchase intention. Public Relations Rev. 36 (2), 193-195.

Lili, M.A., Moraetis, N.D., Nikolaidis, N.P., Karatzas, G.P., Kalogerakis, N., 2015. Characterization and mobility of geogenic chromium in soils and riber bed sediments of Asopos basin. J. Hazard. Mater. 281, 12-19.

Liobikiene, G., Juknys, R., 2016. The role of values, environmental risk perception, awareness of consequences and willingness to assume responsibility for environmentally-friendly behavior: the Lithuanian case. J. Cleaner Prod. 112, 3413-3422.

Liu, M.T., Wong, I.A., Shi, G., Chu, R., Brock, J.L., 2014. The impact of corporate social responsibility (CSR) performance and perceived brand quality on customer-based brand preference. J. Serv. Market. 28 (3), 181-194.

Malovics, G., Csigene, N.N., Kraus, S., 2008. The role of corporate social responsibility in strong sustainability. J. Socio-Econ. 37, 907-918.

Manzo, L.C., Devine-Wright, P., 2013. Place Attachment: Advances in Theory, Methods and Applications. Routledge, pp. 2013.

Mc Gregor, A., Smit, J., 2017. Risk management: human rights due diligence in corporate global supply chains. Governance Directions 69 (1), 16.

McDermott, T.K.J., Barry, F., Tol Richard, S.J., 2014. Disasters and development natural disasters, credit constraints and economic growth. Oxford Econ. Pap. 66 (3), $750-773$.

McLachlan, J., Gardner, J., 2004. A comparison of socially responsible and conventional investors. J. Bus. Ethics 52 (1), 11-25.

Moffat, K., Zhang, A., 2014. The paths to social license to operate: an integrative model explaining community acceptance of mining. Resour. Policy 39, 61-70.

Moon, J., 2007. The contribution of corporate social responsibility to sustainable development. Sustainable Dev. 15 (5), 296-306.

Ogwu, D.S., 2016. Effects of oil exploration on agriculture and natural resources in the Niger Delta region of Nigeria. Sustainable Hum. Dev. Rev. 1 (2).

Okoye, A., 2009. Theorizing corporate social responsibility as an essentially contested concept: is a definition necessary? J. Bus. Ethics 89 (4), 613-627.

Panagopoulos, I., Karayannis, A., Kollias, K., Papassopi, N, 2014. Investigation of potential soil contamination with $\mathrm{Cr}$ and $\mathrm{Ni}$ in four metal finishing facilities at Asopos industrial areas. J. Hazardous Mater. 28, 20-26.

Papatheodorou, A., Pappas, N., 2017. Economic recession, job vulnerability and tourism decision making: a qualitative comparative analysis. J. Travel Res. 50 (5), 663-677.

Pathak, N., Tudu, P.N., Pathak, P., 2014. Acceptability of stakeholders as measure of CSR effectiveness: a study of coal industry. Manage. Insight 10 (1).

Pineiro Chousa, J., Tamazian, A., Vadlamannati, K.C., 2017. Does higher economic and financial development lead to environmental degradation: evidence from BRIC countries. Energy Policy 37 (1).

Pratsinakis, M., Hatziprokopiou, P., King, R., 2017. Beyond migration binance and linear transitions: the complexification of Greece's migratory landscape attitudes of crisis. Working Paper No. 92, Sussex Centre for Migration Research, University of Sussex.

Putnam, R.D., 2000. Bowling Alone: The Collapse and Revival of American Community. Simon and Schuster, New York.

Read, D., Bostrom, A., Morgan, M.G., Fischhoff, B., Smuts, T., 1994. What do people know about global climate change? Survey studies of educated laypeople. Risk Anal. 14 (6), 971-982.

Rubio, S., Vasquez, A., 2016. Do passive institutional investors influence corporate social responsibility? SSRN E-Library.

Rupp, D.E., Wright, P.M., Argree, S., Luo, Y., 2015. Organizational justice behavioral ethics and corporate social responsibility: finally the three shall merge. Manage. Org. Rev. 11 (01), 15-24.

Russo, A., Perrini, F., 2010. Investigating stakeholder theory and social capital: CSR in large firms and SMEs. J. Bus. Ethics 91 (2), 207-221.

Schafft, K.A., Borlu, Y., Glenna, L., 2013. The relationship between Marcellus Shale gas development in Pennsylvania and local perceptions of risk and opportunity. Rural Sociol. 78 (2), 143-166.

Shrivastava, P., 1995a. The role of corporations in achieving sustainability. Acad. Manage. Rev. 20 (4), 936-960.

Shrivastava, P., 1995b. Industrial/environmental crises and corporate social responsibility. J. Socio-Econ. 24, 211-227. 
Sparkes, R., Cowton, C.J., 2004. The maturing of socially responsible investment: a review of the developing link with corporate social responsibility. J. Bus. Ethics 52 (1), 45-47.

Stragham, R.D., Roberts, J.A., 1999. Environmental segmentation alternatives: a look at green consumer behavior in the new millennium. J. Consumer Market. 16 (6), 558-575.

Sy, A., Tinker, T., 2013. From Exxon Valdez to oriental nicety: African environmental issues, accounting and corporate responsibilities. African J. Econ. Sustainable Dev. 2 (3), 189-203.

Szagun, G., Pavlov, V.I., 1995. Environmental Awareness: a comparative study of German and Russian adolescents. Young Soc. 27 (1), 93-112.

Szekely, F., Knirsch, M., 2005. Responsible leadership and corporate social responsibility: metrics for sustainable performance. Eur. Manage. J. 23 (6), 628-647.

Tentes, G., Damigos, D., 2016. The lost value of groundwater: the case of Asopos river basin in central Greece. Water Resour. Manage. 26 (1), 147-164.

Torugsa, N.A., O' Donohue, W., Hecker, R., 2012. Capabilities, proactive CSR and financial performance in SMEs: empirical evidence from an Australian manufacturing industry sector. J. Bus. Ethics 109 (4), 483-500.

Traore, M., 2016. Extractive Industries, the State and Host Communities. A Study of Gold Mining Industry in Ghana. In: Agbesinyale, P., Tenkoracy, E.Y., Dankawah, M. (Eds.), (2012). Journal of Science and Technology (Ghana), 36 (2), 108-113.

Van Liere, K.D., Dunlap, R.E., 1980. The social bases of environmental concern: a review of hypotheses, explanations and empirical evidence. Public Opin. O. 44 (2), 181-197.

Vasileiou, E., Georgantzis, N., 2015. An experiment on energy-saving competition with socially responsible consumers: opening the black box. J. Behav. Exp. Econ. 58, 1-10. Vlachos, P.A., Tsamakos, A., Vrechopoulos, A.P., Avramidis, P., 2009. Corporate social responsibility: attributions, loyalty, and the mediating role of trust. J. Acad. Market. Sci. 37 (2), 170-180

Weber, N.R., Strobel, J., Dyehouse, M.A., Harris, C., David, R., Fang, J., Hua, I., 2014. First year student s environmental awareness and understanding of environmental sustainability through a life cycle assessment module. J. Eng. Edu. 103, 154-181.

Weng, L., Boedhihartono, A.K., Dirks, P.H., Dixon, J., Lubis, M.I., Sayer, J.A., 2013. Mineral industries growth corridors and agricultural development in Africa. Global Food Secur. 2 (3), 195-202.

Wiernik, B., Deniz, S.O., Stephan, D., 2013. Age and environmental sustainability: a metaanalysis. J. Managerial Psychol. 28 (7/8), 826-856.

Zhao, H.-H., Gao, Q., Wu, Y.P., Wang, Y., Zhu, Y.D., 2014. What affects green consumer behavior in China? A case study from Qingdao. J. Cleaner Prod. 63, 143-151.

Zhu, Y., Sun, L.-Y., Leung, A.S.M, 2014. Corporate social responsibility, firm reputation, and firm performance: the role of ethical leadership. Asia Pacific J. Manag. 31 (4), 925-947.

Zsoka, A., Szerényi, Z.M., Széchy, A., Kocsis, T., 2013. Greening due to environmental education on environmental knowledge attitudes, consumer behavior and everyday pro-environmental activities of Hungarian High school university students. J. Cleaner Prod. 48, 126-138.

Zyglidopoulos, S.C., 2001. The impact of accidents on firms' reputation for: performance. Bus. Soc. 40 (4), 416-441. 